\title{
Ruminal acidosis- A case compilation study in SAQ Teaching Veterinary Hospital, Bangladesh
}

\author{
Mahabub Alam¹, Bhajan Chandra Das², Mohammad Mahmudul Hassan³, Md. Ahaduzzaman², Md. Shohel Al Faruk ${ }^{3}$ and \\ Md. Hasanuzzaman
}

1. Department of Animal Science and Nutrition, Chittagong Veterinary and Animal Sciences University, Khulshi, Chittagong-4202, Bangladesh; 2. Department of Medicine and Surgery, Faculty of Veterinary Medicine, Chittagong Veterinary and Animal Sciences University, Khulshi, Chittagong-4202, Bangladesh; 3. Department of Physiology, Biochemistry and Pharmacology; Faculty of Veterinary Medicine, Chittagong Veterinary and Animal Sciences University, Khulshi, Chittagong-4202, Bangladesh

Corresponding author: Mohammad Mahmudul Hassan, email: miladhasan@yahoo.com; Cell: +88-01554326951

Received: 23-10-2013, Revised: 11-12-2013, Accepted: 17-12-2013, Published online: 29-01-2014

doi: $10.14202 /$ vetworld.2014.38-43

How to cite this article: Alam M, Das BC, Hassan MM, Ahaduzzaman M, Faruk MSA and Hasanuzzaman M (2014) Ruminal acidosis- A case compilation study in SAQ Teaching Veterinary Hospital, Bangladesh, Veterinary World 7(1): 38-43.

\begin{abstract}
Aim: A 6-month comprehensive study was undertaken to find out the prevalence, risk factors, and treatment response of ruminal acidosis of cattle and goats at the SAQ Teaching Veterinary Hospital, Chittagong Veterinary and Animal Sciences University, Bangladesh.

Materials and Methods: A total of 609 clinical cases were considered during the study period and the diagnosis of the cases was performed based on detailed history, clinical signs, and clinical examinations including color, odor and consistency of rumen fluid and rumen microflora movements. The confirmations of the cases were done by measuring the $\mathrm{pH}$ of the rumen fluid and the blood. Calcium level of blood was measured by biochemical analyzer to determine hypocalcaemia.

Results: The overall prevalence of ruminal acidosis in ruminants were $2.6 \%$ and found no significant differences $(p>0.05)$ between cattle (4.04\%) and goat (1.9\%). Moreover, there were no significant variation $(p>0.05)$ was observed among the sex (male and female of cattle and goats were $5.1 \% \& 3.4 \%$ and $3.3 \% \& 2.1 \%$, respectively), breeds (non-descriptive and descriptive breeds of cattle and Black Bengal and Jamnapari goats were $3.7 \%$ \& $4.7 \%$ and $1.8 \%$ \& $2.1 \%$, respectively) and two age groups of cattle and goats $(3.7 \% \& 4.3 \%$ and $2.02 \% \& 1.8 \%$, respectively). Among the risk factors of ruminal acidosis feeding of cooked rice was highest (50\% and $62.5 \%$ in cattle and goats, respectively) followed by feeding of rice gruel (25\%) and feeding jackfruit residue, potato, bread each by $12.5 \%$. A positive correlation was observed between duration of illness and ruminal fluid $\mathrm{pH}$ (an increase in the duration of illness increases the ruminal fluid $\mathrm{pH}$ )and a negative correlation between duration of illness and blood $\mathrm{pH}$ (an increase in the duration of illness decreases the serum $\mathrm{pH}$ ). Both ruminal (Orally) and systemic $(\mathrm{I} / \mathrm{V})$ alkalizer were found to be most significant $(\mathrm{p}<0.05)$ treatments for both cattle and goats during the study period.
\end{abstract}

Conclusion: Ruminal acidosis is a vital nutritional problem in ruminants in terms of substantial health problem and economic point of views. This study recommends that farmers should abstain from feeding of the large amount of easily digestible carbohydrates to ruminants at a time.

Keywords: blood pH, cattle, goat, illness, prevalence, risk factors, rumen fluid $\mathrm{pH}$, ruminal acidosis.

\section{I ntroduction}

Livestock plays an important role in the national economy of Bangladesh with direct contribution of around $8 \%$ to the agricultural GDP and providing $32 \%$ of total employment in the economy [1]. Livestock suffers from many infectious and non-infectious diseases. Ruminal acidosis is one of the non-infectious problems of all ruminant species. Many ruminants suffer from ruminal acidosis due to improper feeding practices resulting from lack of knowledge of risk factors. Ruminal acidosis occur when ruminants ingest huge amount of rapidly fermentable carbohydrates, principally starches and sugars [2] or the sudden changes to a diet containing high level of finely ground rapidly fermentable feeds such as corn or wheat. This

Copyright: The authors. This article is an open access article licensed under the terms of the Creative Commons Attribution License (http://creativecommons.org/licenses/by/2.0) which permits unrestricted use, distribution and reproduction in any medium, provided the work is properly cited. may happen in feedlots where feeder steers are introduced to total concentrate diets rather than being gradually changed from high roughage to high concentrate feeds [3]. A large number of farmers are involved in cattle and goat fattening just 3-4 months before Eid-Ul-Azha [4] and most cases ruminal acidosis are reported during this time due to feeding of easily digestible carbohydrate. Lactic acidosis is a clinical condition due to accumulation of $\mathrm{H}^{+}$ions from lactic acid, characterized by blood lactate level $>5 \mathrm{mmole} / \mathrm{L}$ and arterial $\mathrm{pH}<7.25$. Lactic acidosis can cause ruminitis, metabolic acidosis, lameness, pneumonia and death [5]. Diagnosis of the cases can be done based on supporting clinical signs such as complete anorexia, abdominal pain, rapid beating of the heart, abnormally fast breathing, diarrhea, lethargy, diet characteristics and ruminal fluid $\mathrm{pH}$ [6].

The principles of treatment include correction of ruminal and systemic acidosis and prevent further 
Table-1. Treatment schedule for four groups of animals

\begin{tabular}{|c|c|c|c|}
\hline Groups & Animals & Treatment & Route \\
\hline $\begin{array}{l}\text { A } \\
B\end{array}$ & $\begin{array}{l}2 \text { cattle \& } 2 \text { goats } \\
1 \text { cattle \& } 1 \text { goat } \\
1 \text { cattle \& } 1 \text { goat } \\
4 \text { cattle \& } 4 \text { goats } \\
\text { All four groups }\end{array}$ & 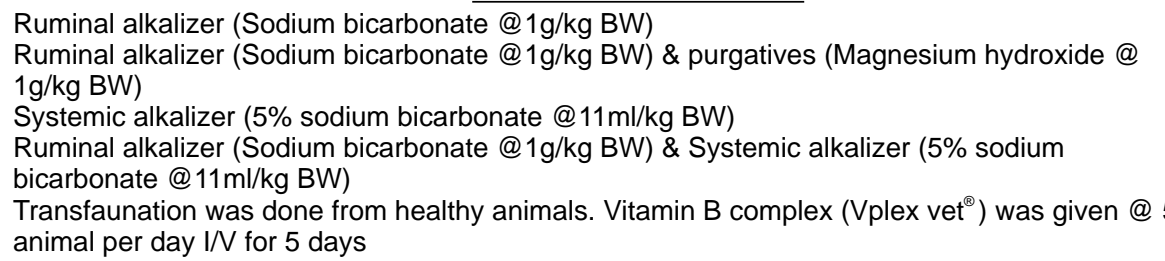 & $\begin{array}{l}\text { Oral } \\
\text { Oral } \\
\text { I/V } \\
\text { Oral + I/V } \\
\mathrm{nl} \mathrm{per}\end{array}$ \\
\hline
\end{tabular}

$\mathrm{BW}=$ Body weight; $\mathrm{I} / \mathrm{V}=\mathrm{Intra}$ venous; [Note: Treatments were continued 12 hours interval for 5 days]

production of lactic acid, restoration of fluid and electrolyte losses and facilitate fore stomach and intestinal motility to normal [7]. Ruminal acidosis is considered the most important nutritional disorder in US feedlots and the dairy industry [8]. Mutsvangwa, [9] estimated the annual cost of sub-acute ruminal acidosis (SARA) to the US dairy industry at $\$ 500$ million to $\$ 1$ billion. In addition, apart from compromises to dairy cow health and economics, SARA is of concern for animal welfare reasons, since lameness and laminitis impact significantly on cow comfort and general well-being $[8,10]$. In Bangladesh, most of the cases ruminal acidosis resulting from accidental intake of large amounts of cooked rice, rice gruel, potato, bread, jackfruit residue or other easily digestible carbohydrates. Now a day's most of the farmers are involved in the fattening of cattle or keep attention to obtain large volumes of milk from animals. But due to ignorance of feeding practice a considerable number of animals affected with ruminal acidosis. Some of the cases, the affected animals are remain unnoticed due to lack of knowledge. Most of the acutely affected animals die due to lack of proper treatment selection, these results a great economic loss in our country. Limited or no study was conducted in Bangladesh to explore prevalence, risk factors and effectiveness of treatment of ruminal acidosis. So, the current research was designed to find out prevalence, risk factors and most effective treatment of ruminal acidosis in cattle and goat.

\section{Materials and Methods}

Study area and study period: The study was conducted at the SAQ Teaching Veterinary Hospital, CVASU, Bangladesh, during the period of July to December, 2012.

Selection of cases: The total numbers of animals reported in hospital were considered to determine the prevalence of ruminal acidosis. Presumptive diagnosis of the cases was made based on history (feeding of easily digestible carbohydrates such as cooked rice, jackfruit residue, potato etc.) and clinical signs includes complete anorexia, abdominal pain, rapid heart rate, abnormally fast breathing, diarrhea, exhibit the lethargic star gaze described by Nordlund, [6] and low ruminal $\mathrm{pH}$, low blood $\mathrm{pH}$ and stop or reduced motility of microflora described by Owens et al., [11].

Collection of samples and evaluation: Rumen fluid was collected by using a 14 gauge, 5 inch long needle attached to a $10 \mathrm{ml}$ disposable syringe. In case of cattle a $2 \times 2 \mathrm{~cm}$ area was marked on the left paralumbar fossa, approximately one hand length ventral to the lumbar transverse process and one hand width caudal to the last rib. In goat the intended area was selected in left paralumbar fossa at a point 3 inches ventral to the lumbar transverse process and 2 inches caudal to the last rib. The selected area was shaved and sterilized with $70 \%$ alcohol and the sampling needle was inserted firmly through into the rumen. Five (5) $\mathrm{ml}$ of rumen fluid was collected by applying back pressure to the piston of syringe. The collected fluid was taken into a sample vial. One (1) $\mathrm{ml}$ of collecting rumen fluid was taken in a watch glass and a piece of $\mathrm{pH}$ indicator paper (Merck- universal indicator $\mathrm{pH}$ 1-14, Merck Limited, Worli, Mumbai-400 018) inserted into the fluid for a few seconds. The color change was observed in $\mathrm{pH}$ indicator paper to determine the $\mathrm{pH}$. To identify the motility of the rumen microflora a drop of fluid was taken into a clean glass slide and after putting a cover slip the content was observed under low power objective (10x). Physical characteristics (Color, consistency and odor) of rumen fluid were determined by using organoleptic test.

Three $\mathrm{ml}$ of blood from the same animal was collected by using a $5 \mathrm{ml}$ sterile disposable plastic syringe attached with 22 gauge needle from the jugular vein. The blood sample was taken into vacutainer that contain anticoagulants (Na-citrate) and centrifugation of blood was done at $1000 \mathrm{rpm}$ for 10 minutes for separation of serum. The collected serum was taken in a watch glass and a piece of $\mathrm{pH}$ indicator paper inserted into the serum for a few seconds. The color change was observed to determine the $\mathrm{pH}$. The serum $\mathrm{Ca}$ level was determined by biochemical analyzer (Humalyzer-3000 Chemistry Analyzer, semi-automated Benchtop chemistry photometer, CHEM- LABS Company, East Africa-Kenya).Confirmatory diagnosis was performed based on rumen fluid $\mathrm{pH}$ described by Khafipour et al., [12] and serum $\mathrm{pH}$ stated by Owens et al., [11].

8 cattle and 8 goats, clinically affected ruminal acidosis was considered for treatment to find out the response to treatment. After treatment, patients were kept under close observation by active and passive participation and recurring cases were observed in hospital.

Statistical analysis: The obtained data were stored in Microsoft excel-2007 and analyzed by using STATA/IC-11. The mean and SEM with 95\% CI were 
Available at www.veterinaryworld.org/Vol.7/Jan-2014/10.pdf

Table-2. Prevalence of ruminal acidosis in different species, sexes, breeds and age groups

\begin{tabular}{|c|c|c|c|c|c|c|}
\hline Categories & & Variables & Positive cases & Negative cases & Prevalence & p-value \\
\hline Species & $(n=609)$ & $\begin{array}{l}\text { Cattle } \\
\text { Goat }\end{array}$ & $\begin{array}{l}8 \\
8\end{array}$ & $\begin{array}{l}190 \\
403\end{array}$ & $\begin{array}{l}4.04 \% \\
1.90 \%\end{array}$ & 0.11 \\
\hline Sex & Cattle $(n=198)$ & $\begin{array}{c}\text { Male } \\
\text { Female }\end{array}$ & $\begin{array}{l}4 \\
4\end{array}$ & $\begin{array}{c}75 \\
115\end{array}$ & $\begin{array}{c}5.10 \% \\
3.4\end{array}$ & 0.41 \\
\hline & Goat $(n=411)$ & $\begin{array}{l}\text { Male } \\
\text { Female }\end{array}$ & $\begin{array}{l}5 \\
3\end{array}$ & $\begin{array}{l}189 \\
214\end{array}$ & $\begin{array}{l}3.3 \\
2.1\end{array}$ & 0.30 \\
\hline Breed & Cattle $(n=198)$ & $\begin{array}{l}\text { ND } \\
\text { HF cross }\end{array}$ & $\begin{array}{l}5 \\
3\end{array}$ & $\begin{array}{l}129 \\
61\end{array}$ & $\begin{array}{l}3.7 \\
4.7\end{array}$ & 0.47 \\
\hline & Goat $(n=411)$ & $\begin{array}{c}\text { BBG } \\
\text { Jamnapari }\end{array}$ & $\begin{array}{l}5 \\
3\end{array}$ & $\begin{array}{l}265 \\
138\end{array}$ & $\begin{array}{l}1.8 \\
2.1\end{array}$ & 0.47 \\
\hline Age & Cattle $(n=198)$ & $\begin{array}{l}<2 \text { years } \\
>2 \text { years }\end{array}$ & $\begin{array}{l}3 \\
5\end{array}$ & $\begin{array}{c}79 \\
111\end{array}$ & $\begin{array}{l}3.7 \\
4.3\end{array}$ & 0.45 \\
\hline & Goat $(n=411)$ & $\begin{array}{l}<11 / 2 \text { years } \\
>11 / 2 \text { years }\end{array}$ & $\begin{array}{l}6 \\
2\end{array}$ & $\begin{array}{l}291 \\
112\end{array}$ & $\begin{array}{c}2.02 \\
1.8\end{array}$ & 0.41 \\
\hline
\end{tabular}

Table-3. Descriptive Statistics of different parameters of cattle and goat

\begin{tabular}{llllll}
\hline Variables & \multicolumn{2}{c}{ Cattle } & & \multicolumn{2}{c}{ Goat } \\
\cline { 2 - 3 } \cline { 5 - 6 } & Mean \pm SD & Range & & Mean \pm SD & Range \\
\hline Temperature $\left({ }^{0} \mathrm{~F}\right)$ & $101.06 \pm 1.24$ & $99.5-103$ & & $103.01 \pm 1.14$ & $101-105$ \\
Rumen motility/5 minutes & $3.25 \pm 2.60$ & $0-7$ & & $4.00 \pm 2.20$ & $1-7$ \\
Ruminal fluid $\mathrm{pH}$ & $5.01 \pm 0.63$ & $4.2-6$ & & $4.90 \pm 0.63$ & $4-5.8$ \\
Serum pH & $7.16 \pm 0.23$ & $6.8-7.4$ & & $7.16 \pm 0.20$ & $6.8-7.4$ \\
Serum calcium (mg/dl) & - & - & & $9.09 \pm 1.26$ & $7.65-11.32$ \\
\hline
\end{tabular}

Table-4. Analysis of risk factors involved in occurrence of ruminal acidosis in cattle and goat

\begin{tabular}{llccl}
\hline Species & Categories of feed & Cases & Percentage (\%) & $\mathbf{9 5 \%} \mathbf{~ C l}$ \\
\hline Cattle & Cooked rice & 4 & 50 & $5.31-94.7$ \\
& Potato & 1 & 12.5 & $17.05-42.05$ \\
& Jackfruit residue & 1 & 12.5 & $17.05-42.05$ \\
& Bread & 1 & 12.5 & $17.05-42.05$ \\
\multirow{4}{*}{ Goat } & Palm & 1 & 12.5 & $17.05-42.05$ \\
& Cooked rice & 5 & 62.5 & $19.2-105.7$ \\
& Rice gruel & 2 & 25 & $13.7-63.7$ \\
& Bread & 1 & 12.5 & $17.05-42.05$ \\
\hline
\end{tabular}

calculated to express the variables. The comparisons of variables within species, breeds, sex and age groups were done by using Epi info software. The level of significance determined by one way ANOVA and $p<0.05$ considered as significant.

\section{Results}

A total of 609 ruminant animals (both cattle and goats) were recorded during the study period, among them 16 were identified with ruminal acidosis and overall prevalence was $2.6 \%$.

Table-2 describes the prevalence of ruminal acidosis in different species, sexes, breeds and age groups of animals. There were found no significant variation $(p>0.05)$ of the prevalence among the cattle $(4.04 \%)$ and goats $(1.9 \%)$, between male and female of cattle $(5.1 \%$ and $1.9 \%)$ and goat $(3.3 \%$ and $2.1 \%)$, between Non Descriptive (ND) (3.7\%) and Holstein Friesian cross (HF cross) breed (4.7\%) cattle, between Black Bengal goat (1.8\%) and Jamnapari goat (2.1\%) and between different age groups of cattle $3.7 \%$ in $<2$ year's cattle and $4.3 \%$ in $>2$ year's cattle) and goat $\left(2.02 \%\right.$ in $<1 \frac{1}{2}$ year's goats and $1.8 \%$ in $>1 \frac{1}{2}$ year's goat).

The mean temperature, rumen motility per 5 minutes, rumen fluid $\mathrm{pH}$ and serum $\mathrm{pH}$ of the affected cattle were $101.06 \pm 1.24{ }^{\circ} \mathrm{F}, 3.25 \pm 2.6,5.01 \pm 0.63$ and $7.16 \pm 0.23$, respectively. Moreover, affected goat were showed $103.01 \pm 1.14^{\circ} \mathrm{F}, 4 \pm 2.20,4.9 \pm 0.63$ and $7.16 \pm 0.2$, respectively. In addition, the mean serum calcium level of goat was $9.09 \pm 1.26 \mathrm{mg} / \mathrm{dl}$ (Table-3).

The occurrences of ruminal acidosis in cattle were found $50 \%$ due to cooked rice followed by $12.5 \%$ cases due to potato, jackfruit residue, bread and palm. On the other hand, in goat $62.5 \%$ cases were due to cooked rice followed by $25 \%$ and $12.5 \%$ cases due to rice gruel and bread, respectively (Table-4).

During the rumen fluid examination, the presence of rumen flora movement under the microscope was observed $12.5 \%$ in cattle and $25 \%$ in goat. The color of rumen fluid was greenish, greenish brown and milky gray in $25 \%$ and $37.5 \%, 12.5 \%$ and $25 \%, 62.5 \%$ and $37.5 \%$, respectively in cattle and goat. The consistency of rumen fluid was found watery $(25 \% \& 37.5 \%)$, thick watery $(50 \% \& 25 \%)$, and gruel like $(25 \% \& 37.5 \%)$ in cattle and in goat. Most of the cases $(87.5 \%)$ the odor of the rumen fluid were sour in both species (Table-5).

A positive correlation between the duration of illness of different cases and ruminal fluid $\mathrm{pH}$ (an increase in the duration of illness also increases the ruminal fluid $\mathrm{pH}$ up to the certain level) and a negative correlation between the duration of illness and serum $\mathrm{pH}$ (an increase in the duration of illness results decreases the serum $\mathrm{pH}$ up to a certain level) were observed. These correlations in case of cattle and goats are plotted in Figure-1. 
Available at www.veterinaryworld.org/Vol.7/Jan-2014/10.pdf

Table-5. Analysis of different characteristics of rumen fluid in ruminal acidosis in cattle and goat

\begin{tabular}{|c|c|c|c|c|c|}
\hline \multirow[t]{2}{*}{ Variables } & \multirow[t]{2}{*}{ Categories } & \multicolumn{2}{|c|}{ Cattle } & \multicolumn{2}{|c|}{ Goat } \\
\hline & & Cases (\%) & $95 \% \mathrm{Cl}$ & Cases (\%) & $95 \% \mathrm{Cl}$ \\
\hline Movement of microflora & $\begin{array}{l}\text { Present } \\
\text { Absent }\end{array}$ & $\begin{array}{l}1(12.5) \\
7(87.5)\end{array}$ & $\begin{array}{l}17.05-42.05 \\
57.9-117.05\end{array}$ & $\begin{array}{l}2(25) \\
6(75)\end{array}$ & $\begin{array}{l}13.7-63.7 \\
36.2-113.7\end{array}$ \\
\hline Color & $\begin{array}{l}\text { Greenish } \\
\text { Greenish brown } \\
\text { Milky grey }\end{array}$ & $\begin{array}{l}2(25) \\
1(12.5) \\
5(62.5)\end{array}$ & $\begin{array}{l}13.7-63.7 \\
17.05-42.05 \\
19.2-105.7\end{array}$ & $\begin{array}{l}3(37.5) \\
2(25) \\
3(37.5)\end{array}$ & $\begin{array}{l}5.7-80.7 \\
13.7-63.7 \\
5.7-80.7\end{array}$ \\
\hline Consistency & $\begin{array}{l}\text { Watery } \\
\text { Thick watery } \\
\text { Gruel like }\end{array}$ & $\begin{array}{l}2(25) \\
4(50) \\
2(25)\end{array}$ & $\begin{array}{l}13.7-63.7 \\
5.31-94.7 \\
13.7-63.7\end{array}$ & $\begin{array}{l}3(37.5) \\
2(25) \\
3(37.5)\end{array}$ & $\begin{array}{l}5.7-80.7 \\
13.7-63.7 \\
5.7-80.7\end{array}$ \\
\hline Odor & $\begin{array}{l}\text { Sour } \\
\text { Pungent }\end{array}$ & $\begin{array}{l}7(87.5) \\
1(12.5)\end{array}$ & $\begin{array}{l}57.9-117.05 \\
17.05-42.05\end{array}$ & $\begin{array}{l}7(87.5) \\
1(12.5)\end{array}$ & $\begin{array}{l}57.9-117.05 \\
17.05-42.05\end{array}$ \\
\hline
\end{tabular}

Table-6. Response of different groups of animals in different treatments

\begin{tabular}{lcclc}
\hline Group & Cases & Treatment response (days) & p- value & Level of significance \\
\hline A & 4 & $7.00 \pm 0.41$ & 1.00 & NS \\
B & 2 & $7.00 \pm 1.00$ & 0.001 & $*$ \\
A & 4 & $7.00 \pm 0.41$ & 0.00 & $*$ \\
C & 2 & $4.50 \pm 0.50$ & & $*$ \\
A & 4 & $7.00 \pm 0.41$ & 0.02 & $*$ \\
D & 8 & $1.81 \pm 0.09$ & 0.00 & $*$ \\
B & 2 & $7.00 \pm 1.00$ & & $*$ \\
B & 2 & $4.50 \pm 0.50$ & 0.00 & $*$ \\
D & 2 & $7.00 \pm 1.00$ & & $*$ \\
C & 8 & $1.81 \pm 0.09$ & & \\
D & 2 & $4.50 \pm 0.50$ & $1.81 \pm 0.09$ &
\end{tabular}

NS $=$ Non significant, $*=$ Significant, $* *=$ Highly significant
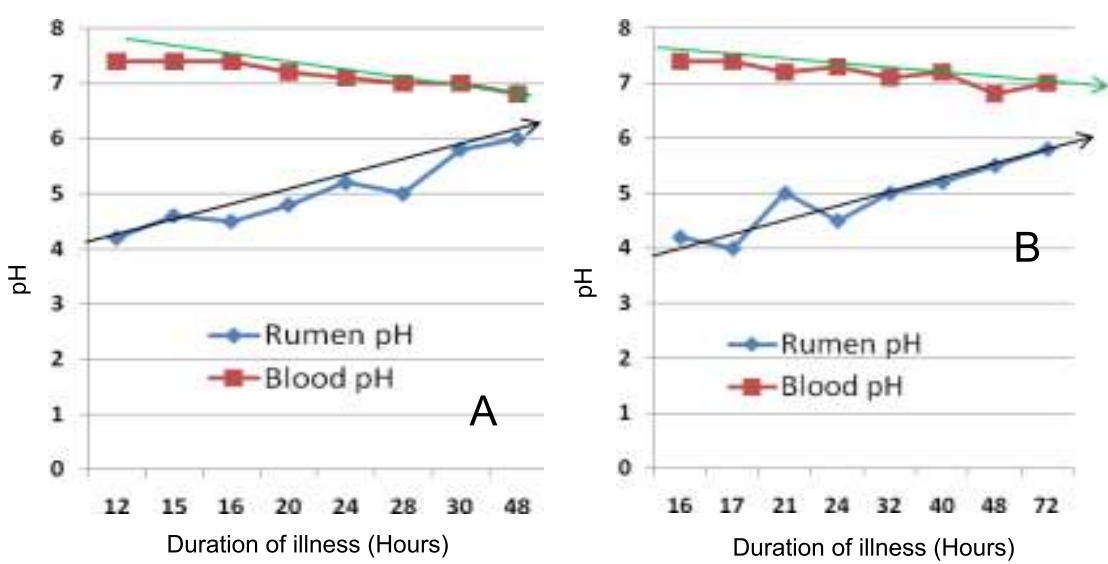

Figure-1. Changes in rumen and blood $\mathrm{pH}$ in relation with time elapse after onset of illness in Cattle (A) and Goat (B).

Table- 6 describe the response to treatment of different groups of animals. It was revealed that there was no statistically significant difference in response to treatment between group A and B $(\mathrm{P}>0.05)$. This study also revealed that in comparison between other groups (Except, between A and B) has significant differences $(p<0.05)$ in response to treatment. Any comparison with group D with other group, the difference in response to treatment was highly significant $(p=0.00)$. So treatment with both ruminal alkalizer and systemic alkalizer is the most effective treatment and animal response more quickly (within $1.81 \pm 0.09$ days) than other types of treatments.

\section{Discussion}

The overall prevalence of ruminal acidosis found $2.6 \%$ in the current study which is not similar to the findings of kleen et al., [13] who found a herd prevalence of $20 \%$ in case of sub-acute acidosis in cattle of
Germany. Krause and Oetzel, [14] showed 4\% prevalence of clinical acidosis in feedlot which is more or less similar. A number of researchers found higher prevalence of subacute ruminal acidosis $[7,13,15,16]$. There were no significant differences observed in the prevalences between the species, breeds, sex and age groups and these findings agree with Radostits et al., [7] who reported all types of ruminant are susceptible to ruminal acidosis. It was revealed that sudden ingestion of large amount of easily digestible carbohydrates predisposed the ruminal acidosis in most of the cases which agree with several researchers [2,17] who mentioned easily digestible carbohydrates or grain act as predisposing factors of ruminal acidosis.

In most of the cases a remarkable change in the physical characteristics of ruminal fluid were observed during the period of rumen acidosis, such as becoming milky color, watery consistency, and souring odor. These findings were in agreement with Jasmin et al., 
[18] who reported changes were similar to events observed in sheep with rumen acidosis. In the present study, the rumen fluid $\mathrm{pH}$ was found to be in between 4.2-6.0 which is almost similar to findings of Nagaraja and Titgemeyer, [19] and Plaizier et al., [20], reported ranges between 5.0-6.16 in ruminal acidosis in beef cattle and dairy cows, respectively. In the present study there were falls of blood $\mathrm{pH}$ in both cattle and goat which agree with Brown et al., [21] who reported falls of blood pH below 7.3. Hypocalcaemia was found in four cases and the finding has similarities with Divers and Peek, [3] who reported hypocalcaemia in ruminal acidosis. Positive correlation was found between the duration of illness of different cases and ruminal fluid $\mathrm{pH}$ and the finding has similarities with Kleen et al., [22] who attribute this decrease in $\mathrm{pH}$ alteration is due to changes rumen microflora. Sato et al., [23] also reported on his study of induced acidosis on cross breed goat were found similar correlations between rumen $\mathrm{pH}$ and duration of induction.

Afonso et al., [24] reported that clinical recovery of animals depends on the rumen $\mathrm{pH}$ (above 6). Both ruminal and systemic alkalizer were effective treatment against ruminal acidosis and the findings have similarities with Khafipour et al., [12]. On the other hand, Redostits et al., [7] suggested using ruminal antacids orally to neutralize the ruminal acids and intravenous hypertonic sodium bicarbonate to neutralize systemic acidosis and correction of dehydration. From the above correlation between rumen fluid and blood $\mathrm{pH}$ of different cases in relation to duration of illness, treatment with ruminal and systemic alkalizer will be recommended.

\section{Conclusion}

Ruminal acidosis is a substantial health problem and an important nutritional problem in ruminants in terms of the economic point of view. The overall prevalence of ruminal acidosis in ruminant was $2.63 \%$ and prevalence in cattle and goats were $4.04 \%$ and $1.9 \%$, respectively. The causes of ruminal acidosis is not apathogen, but self-created complications by the owner and the major predisposing factor is malpractice in feeding. Color, consistency, and odor of rumen fluid, movements of ruminal flora, $\mathrm{pH}$ of the rumen fluid and blood, and hypocalcaemia gives the clues for diagnosis. Ruminal and systemic alkalizer are used to correct ruminal acidosis and provide a quick solution in both cattle and goats. Proper feeding practices should be advised to the farmers to reduce the risk of ruminal acidosis in ruminants.

\section{Authors' contributions}

MA and MMH implemented the study design and carried out the laboratory experimentation. MA, MMH, MA, MSAF, BCD and MH drafted and revised the manuscript. All authors read and approved the final version of the manuscript.

\section{Acknowledgements}

The authors are grateful to the staffs of the SAQ
Teaching Veterinary Hospital, Chittagong Veterinary and Animal Sciences University and Department of Physiology, Biochemistry \& Pharmacology for their contentious support to the present research.

\section{Competing interests}

The authors declare that they have no competing interests.

\section{References}

1. Ministry of Fisheries and Livestock (2013) National Livestock Development Policy. Government of People's Republic of Bangladesh, Dhaka, Bangladesh. http://www. mofl.gov.bd. Accessed on 07-12-2013.

2. Beauchemin, K. and Penner, G. (2009) New developments in understanding ruminal acidosis in dairy cows. Tri-State Dairy Nutrition Conference, 21-22 April 2009, pp: 1-12.

3. Divers, T.J. and Peek, S.F. (2008) Diseases of Dairy Cattle: Noninfectious diseases of the gastrointestinal tract. $2^{\text {nd }}$ ed., Missouri, Saunders, 130-199.

4. Sarma, P.K. and Ahmed, J.U. (2011) An economic study of small scale cattle fattening enterprise of Rajbari district. $J$. Bangladesh Agril. Univ., 9(1):141-146.

5. Lean, I. J. and Wade, L. K. (2000) New Approaches to Control of Ruminal Acidosis in Dairy Cattle. AsianAustralas. J. Anim. Sci., 13 (1):266-269.

6. Nordlund, K.V. (2004) Investigation strategies for laminitis problem herds. J. Dairy Sci., 87: 27- 35.

7. Redostits, O.M., Gay, C.C., Blood, D.C., Hinchcliff, K.W. and Constable, P.D. (2006) Diseases of the alimentary tract. In Veterinary Medicine, $10^{\text {th }}$ ed., Saunders, Edinburg, 169-250.

8. Oetzel, G.R. (2003) Subacute ruminal acidosis in dairy cattle. J. Dairy Sci., 15:307317.

9. Mutsvangwa, T. (2013) Sub-Acute Ruminal Acidosis (SARA) in Dairy Cow. http://www.omafra.gov.on.ca/ english/livestock/dairy/facts/03-031.htm. Accessed on 0712-2013.

10. Hall, M.B. and Averhoff, K.S. (2000) The real costs of digestive upset. $37^{\text {th }}$ Florida Dairy Production Conference, Gainesville, May, 2-3, 2000, 99-104.

11. Owens, F.N., Secrist, D.S., Hill, W.J. and Gill, D.R. (1998) Acidosis in cattle: Areview. J. Anim. Sci., 76:275-286.

12. Khafipour, E., Shucong, L., Plaizier, J.C. and Krause, D.O. (2009) Rumen microbiome composition determined using two nutritional models of subacute ruminal acidosis. Appl. Environ. Microbiol., 75: 7115-7124.

13. Kleen, J. L., Upgang, L. and Rehage, J. (2013) Prevalence and consequences of subacute ruminal acidosis in German dairy herds. Acta Veterinaria Scandinavica, 55:48.

14. Krause, M.K. and Oetzel, G.R. (2006) Understanding and preventing subacute ruminal acidosis in dairy herds: A review. Anim. Feed Sci. Technol., 126: 215-236.

15. Nogues, A. (2013) Sub-Acute Ruminal Acidosis (SARA). http://www.ecow.co.uk/sub-acute-ruminal-acidosis-sara/. Accessed on 07-12-2013.

16. Kleen, J.L., Hooijer, G.A., Rehage, J. and Noordhuizen, J.P.T.M. (2004) Rumenocentesis (rumen puncture): a viable instrument in herd health diagnosis. German Vet. Weekly, 111: $458-462$

17. Penner, G.B., Beauchemin, K.A. and Mutsvangwa, T. (2007) Severity of ruminal acidosis in primiparous Holstein cows during the periparturient period. J. Dairy Sci., 90: 365375 .

18. Jasmin, B. H., , R. C., Modesto, R. B. and Schaer, T. P. (2011) Perioperative Ruminal pH Changes in Domestic Sheep (Ovis aries) Housed in a Biomedical Research Setting, J. Am. Assoc. Lab. Anim. Sci., 50(1): 27-32.

19. Nagaraja, T.G. and Titgemeyer, E.C. (2007) Ruminal acidosis in beef cattle: the current microbiological and nutritional outlook. J. Dairy Sci., 90 (E):17-38.

20. Plaizier, J.C., Krause, D.O., Gozho, G.N. and McBride, B.W. (2008) Subacute ruminal acidosis in dairy cows: the 
physiological causes, incidence and consequences. Vet. J., 176: 21-31.

21. Brown, M.S., Krehbiel, C.R., Galyean, M.L., Remmenga, Peters, J.P., Hibbard, B., Robinson, J., Moseley, W.M. (2000) Evaluation of models of acute and subacute acidosis on dry matter intake, ruminal fermentation, blood chemistry, and endocrine profiles of beef steers. J. Anim. Sci., 78: 3155-3168.

22. Kleen, J. L., Hooijer, G. A., Rehage, J. and Noordhuizen, J. P. T. M. (2003) Subacute Ruminal Acidosis (SARA): a Review.J. Vet. Med. Series A, 50: 406-414.
23. Sato, S., Mizuguchi, H., Ito, K., Ikuta, K., Kimura, A. and Okada, K. (2012) Development and testing of a radio transmission $\mathrm{pH}$ measurement system for continuous monitoring of ruminal $\mathrm{pH}$ in cows. Prev. Vet. Med., 103:274279.

24. Afonso, J.A.B., Ciarlini, P.C., Kuchembuck, M.R.G., Kohayagawa, A., Feltrin, L.P.Z., Ciarlini, L.D.R.P., Laposy, C.B., Mendonca, C.L. and Takahira, R.K. (2002) Neutrophil oxidative metabolism of sheep treated with monensin and experimentally subjected to rumen acidosis. Brazilian J. Vet. Res., 22:129-134.

$* * * * * * * *$ 